\title{
Crianças Expostas: um estudo da prática do enjeitamento em São João del Rei, séculos XVIII e XIX
}

\section{Exposed children: a study concerning rejection in the city of São João del Rei, $18^{\text {th }}$ and $19^{\text {th }}$ centuries}

\section{Silvia Maria Jardim Brügger}

O fenômeno da exposição de crianças foi comum durante todo o período colonial e imperial brasileiros. ${ }^{1}$ Em função disto, em diversos locais, as Santas Casas de Misericórdia estabeleceram rodas para o recolhimento dos enjeitados ${ }^{2}$. Antes disto, porém, ou nos locais em que não havia rodas, a prática era a exposição em casas particulares. Embora esta modalidade de exposição tenha sido mais difundida no Brasil, tanto cronológica como espacialmente, como destacou Bacellar ${ }^{3}$, tem sido menos estudada pelos historiadores do que a primeira, em função, sobretudo, da maior disponibilidade documental oferecida ao pesquisador pelas Santas Casas ${ }^{4}$.

Para o estudo da exposição particular, dispõem-se principalmente de informações contidas em documentação serial, como registros paroquiais, listas nominativas e testamentos, por isto, as poucas análises a este respeito inserem-se em obras mais gerais sobre as relações familiares, que, ao reconstituírem seus laços, acabam deparando-se com o fenômeno do enjeitamento de crianças e se debruçando, em maior ou menor grau, sobre ele 5 .

\section{A Prática da Exposição de Crianças em São João del Rei}

Em São João del Rei, o fenômeno da exposição foi bastante difundido, como se pode notar na análise dos registros paroquiais de batismo. 
Tabela 1 - Número de Expostos por Década em Relação ao Total de Batismos de Filhos de Mães Livres e Forras

\begin{tabular}{|c|cc|cc|}
\hline Período & \multicolumn{2}{|c|}{ Expostos Batizados* } & \multicolumn{2}{c|}{$\begin{array}{c}\text { Total de Filhos de } \\
\text { Mães Livres e Forras }\end{array}$} \\
\hline $1736-1740$ & 18 & $4,1 \%$ & 439 & $100 \%$ \\
$1741-1750$ & 31 & $2,9 \%$ & 1075 & $100 \%$ \\
$1751-1760$ & 7 & $1,7 \%$ & 423 & $100 \%$ \\
$1761-1770$ & 135 & $7,3 \%$ & 1853 & $100 \%$ \\
$1771-1780$ & 101 & $7,9 \%$ & 1276 & $100 \%$ \\
$1781-1790$ & 364 & $9,8 \%$ & 3704 & $100 \%$ \\
$1791-1800$ & 451 & $10,2 \%$ & 4403 & $100 \%$ \\
$1801-1810$ & 355 & $8,8 \%$ & 4051 & $100 \%$ \\
$1811-1820$ & 409 & $8,8 \%$ & 4669 & $100 \%$ \\
$1821-1830$ & 223 & $8,0 \%$ & 2802 & $100 \%$ \\
$1831-1840$ & 67 & $4,7 \%$ & 1433 & $100 \%$ \\
$1841-1850$ & 45 & $2,9 \%$ & 1571 & $100 \%$ \\
\hline Total & 2206 & $8,0 \%$ & 27699 & $100 \%$ \\
\hline
\end{tabular}

Fonte: MNSP-SJDR. Registros Paroquiais de Batismo, 1736-1850.

* Excluídos dois casos de crianças que foram expostas a escravos.

A proporção de expostos em relação ao número total de batismos de livres e forros é realmente significativa: $8 \%$, ao longo de todo o período estudado $^{6}$. Bacellar, trabalhando com informações relativas à Vila de Sorocaba, entre 1679 e 1845 , encontrou um índice global de exposição da ordem de 4,12\% dos batismos de livres ${ }^{7}$. Na Freguesia de São Salvador dos Campos dos Goitacazes, Sheila de Castro Faria encontrou um índice de exposição, entre 1754 e 1786 , de $5,5 \%^{8}$.

A análise da distribuição do fenômeno por décadas, em São João del Rei, destaca o período de 1761 a 1830 como aquele em que esta prática se fez mais presente. $\mathrm{O}$ crescimento percentual da exposição da década de 1750 para a seguinte é muito expressivo: de 1,7\% dos batismos, passa a representar 7,3\%. A década de 1760 representa um momento de certa instabilidade econômica, na região, com o declínio da mineração e um redirecionamento das atividades produtivas e da organização familiar ${ }^{9}$, que 
neste caso se refletiria num aumento do enjeitamento das crianças. Até o final do século XVIII, a tendência ao aumento desta prática se mantém e, a partir de então, passa a declinar ligeiramente. É, contudo, apenas na década de 1830 que se nota um declínio mais contundente neste índice.

Tendência semelhante a esta é apontada pela pesquisa de Bacellar, para Sorocaba. Segundo ele, a exposição cresceu ao longo da segunda metade do século XVIII, atingindo seu percentual máximo, de 1791 a 1800 - 10,38\%, enquanto no decênio de 1761 a 1770 havia sido de 5,26\% e, de 1751 a 1760 , de $3,55 \%{ }^{10}$. No século XIX, o índice decai: de 1801 a 1810, é de 7,58\%; de 1811 a 1820 , de $4,11 \%$; de 1821 a 1830 , de 3,24\%; de 1831 a 1840 , de $1,54 \%$; e, de 1841 a 1845 , de $0,18 \%{ }^{11}$. O autor relaciona as variações à economia tropeira da região, uma vez que quadro semelhante teria sido encontrado para a região de Lapa, no Paraná, também dedicada àquela atividade ${ }^{12}$. Mas, uma explicação mais sólida para as mudanças não é apresentada. Nas palavras do autor,

De fato, conhecer o porquê dos avanços e recuos desse fenômeno requer um conhecimento muito mais amplo da sociedade tropeira, principalmente na primeira metade do século XIX, quando a presença de expostos nas vilas passou a tornar-se cada vez menos usual. No momento, as conclusões devem permanecer na constatação, evidentemente pioneira, de que havia, nos abandonos, um padrão regional, de evolução distinta, diretamente relacionado a uma economia específica, de transporte e comercialização de $\operatorname{gado}^{13}$.

Embora também São João del Rei se constituísse numa importante região comercial, na qual o tropeirismo se fazia presente de modo marcante, não sei se a explicação para as oscilações nos índices de exposição podem ser entendidos apenas por este aspecto. $\mathrm{O}$ crescimento da exposição, em finais dos setecentos, foi observado também por Laura de Mello e Souza, ao estudar o fenômeno em Mariana. Segundo a autora,

Tal evidência tem (...) relação direta com as dificuldades enfrentadas pela capitania, advindas da crise mineratória e dos impasses ante a reorientação oficial das atividades econômicas: seja porque os pais não tinham meios suficientes para arcar com a criação dos filhos, seja porque, estrategicamente, expunham os filhos a fim de obter, de modos indiretos, o financiamento de sua manutenção. Não se pode contudo desconsiderar o aumento 
populacional da capitania no terceiro quartel do século, indicado por gama variada de fontes, e que, por razóes óbvias, implicaria no aumento de nascimentos não-desejáveis ${ }^{14}$.

Parece-me que os argumentos apresentados são plausíveis para explicar o aumento da exposição também em São João del Rei ${ }^{15}$. Já o declínio da prática deve estar ligado à criação da Roda de Expostos pela Santa Casa da Misericórdia de São João del Rei, em $1832^{16}$. Segundo Venâncio, supunha-se que as Rodas seriam um mecanismo de inibição dos abandonos, uma vez que implicavam a entrega da criança a uma instituição e em uma maior ruptura dos laços familiares. Parece que, ao menos em São João del Rei, esta suposição se fez realidade, uma vez que, a partir da década de 1830, os enjeitamentos declinam de maneira acentuada.

\section{Razões das Exposições}

A compreensão, porém, do fenômeno da exposição de crianças não se pode ater apenas às suas oscilações quantitativas. Algumas questões difíceis de serem respondidas são constantemente levantadas quando do estudo do ato de enjeitar: Quem eram estas crianças e seus pais biológicos? Por que "abandonavam" seus filhos? Quem os recebia? Por que aceitavam este encargo? A formulação das perguntas é, certamente, mais fácil do que suas respostas. Apesar disto, alguns elementos podem ser indicados na busca de encontrá-las.

A distribuição sexual das crianças enjeitadas indica uma situação de igualdade: 1087 (49,8\%) homens e 1097 (50,2\%) mulheres ${ }^{17}$. Tendência semelhante a esta foi encontrada também por Bacellar para Sorocaba, e para outras regiōes da colônia, por ele citadas, a partir de trabalhos de diferentes pesquisadores ${ }^{18}$. Ao que tudo indica, realmente não havia uma discriminação de gênero na exposição de crianças, no Brasil Colônia e Império. Não seria, pois, por um atributo específico - no caso, de gênero - que os filhos seriam expostos. As explicações para o enjeitamento deviam recair em fatores relativos à vida de seus pais biológicos.

Uma primeira pista para a identificação dos progenitores das crianças pode ser buscada na sua cor. Trabalhos sobre os expostos em Rodas têm indicado um predomínio de crianças brancas entre os enjeitados. 
Russel-Wood aponta que, na Santa Casa de Salvador, em 1757 e 1758, dentre as 102 crianças expostas, $73 \%$ eram brancas ${ }^{19}$. Venâncio afirma, para o Rio de Janeiro dos séculos XVIII e XIX, a raridade de negros entre os enjeitados ${ }^{20}$. Sheila de Castro Faria toma estes dados - na medida em que os registros paroquiais da Freguesia de São Salvador dos Campos dos Goitacazes, por ela trabalhados, não trazem informações relativas à cor das crianças para afirmar a raridade de negros e mestiços entre os enjeitados, deduzindo daí não ser a pobreza a principal responsável pelo abandono. Nas palavras da autora,

Poderíamos questionar, obviamente, a avaliação da cor, feita pelos que registraram estas crianças. Muitas vezes, uma mestiçagem, ao nascer, não é muito óbvia. O que importa ressaltar, entretanto, é que as crianças não eram explicitamente negras ou mestiças. (...) Se é certo que os mais pobres estão entre os descendentes de escravos, podemos supor que a menor proporção de negros entre os expostos atesta o fato de que a pobreza não era o motivo primordial do abandono de crianças, apesar de o poder ter sido em casos específicos ${ }^{21}$.

Mesmo com a grande ausência de informação da cor das crianças nos registros paroquiais de batismo de São João del Rei, alguns indícios podem ser apontados. Entre os expostos que tiveram sua cor explicitada pelos párocos, 44 eram brancos, um, cabra, um, mulato, 40, pardos, e um, preto. Em princípio, este panorama poderia indicar um maior equilíbrio entre brancos e não-brancos na exposição de crianças em São João del Rei, do que nas regiōes acima mencionadas, no entanto, parece-me que o fato merece uma leitura menos linear. Em geral, quando nenhuma cor/condição é atribuída, nas fontes, a uma pessoa, a tendência é de que seja considerada "branca". Assim também não deveriam ser considerados os expostos cujas cores não fossem registradas? Por outro lado, trabalhos importantes da historiografia recente têm indicado não serem as designaçôes de cor fruto simplesmente da pigmentação da pele, remetendo mais do que isto a um lugar social ${ }^{22}$. Neste sentido, ser branco é, sobretudo, ser livre, negro era o escravo e preto, em especial, o de origem africana. Ora, as crianças expostas eram legalmente livres ${ }^{23}$. Assim sendo, parece-me que dificilmente se poderia registrá-las como pretas. Também para elas, a afirmação de serem brancas, ou pelo menos a ausência de qualquer designação de 
cor/condição, significaria a garantia de sua liberdade, ainda que a pigmentação de suas peles pudesse ser distinta. Desta forma, não creio que se possa inferir da informação a raridade de "descendentes de escravos" entre os progenitores dos enjeitados.

Dentre os registros de batismo de São João del Rei, encontra-se um, do seguinte teor:

Aos vinte e oito dias do mês de outubro de 1765, na Capela de Nossa Senhora da Conceição da Barra, filial da Matriz de Nossa Senhora do Pilar desta Vila de São João del Rei, o Reverendo Padre Manoel Correa de Oliveira batizou e pôs os santos óleos a Manoel exposto em casa de Domingas Ferreira; foram padrinhos Manoel Martins e Domingas Ferreira (... $)^{24}$.

Em princípio, nenhuma informação se poderia tirar deste registro a respeito dos progenitores da criança, que poderia ser tida - pela ausência de menção à sua cor - como branca. No entanto, junto ao assento constam transcritas partes de um processo, iniciado com uma petição encaminhada por Domingos Alves Canjica ao Vigário da Vara. Nela, argumentava ser aquela criança filha de uma sua escrava, Josefa, crioula solteira, a qual, em suas palavras

(...) pejando e parindo um mulatinho, por ocasião do parto, por malignidade desta [da mãe], e induções do sujeito de quem pejou, [ilegível] subrepticiamente, sem que o suplicante e sua mulher fossem sabedores [ilegível] arrebataram a dita criança e se enjeitou em distância de uma légua pouco mais ou menos, em casa de uma mulher solteira, por nome Domingas Ferreira, e logo depois se batizou na dita Capela da Conceição em 28 de outubro de 1765 como exposto em casa desta $(. . .)^{25}$.

Parece claro, neste caso, que a mãe cativa buscava, com a exposição do filho, uma forma para garantir-lhe a liberdade, mesmo antes da legislação portuguesa reafirmar, em 1775, a "ingenuidade" dos expostos. Parece que, na prática, este reconhecimento era anterior à lei lusa ${ }^{26}$. É interessante ainda chamar a atenção para o fato de que o capelão que realizara o batizado afirmou, no decorrer do processo, que, dias depois de sua celebração, ouvira dizer ser a criança filha daquela escrava, mas deste

(...) dito não fiz caso, nem averigüei os seus princípios por me não importar, só agora, sendo-me apresentada a petição retro com o despacho 
de meu Reverendo Ministro, inquiri novamente do caso, e informando-me com a sobredita Josefa crioula, mãe do enjeitado, me disse que certamente era seu e o mandara enjeitar na casa da sobredita Domingas Ferreira, por ocultá-lo de seu senhor por medo que dele tinha, e informando-me com mais algumas pessoas que disto podiam saber, cujos nomes oculto por mo pedirem, assim venho a inferir ser certo o que na petição se alega $(. . .)^{27}$.

Portanto, mesmo tendo notícias da possibilidade de ser o exposto, na verdade, escravo, o padre não tomara qualquer atitude, por não ter na questão nenhum interesse. Foi a iniciativa do senhor que efetivamente impediu o sucesso do projeto que a escrava Josefa traçara para garantir a liberdade de seu filho. E foi só pelo malogro do plano que se pôde descobrir a história. Casos semelhantes, mas bem sucedidos, estarão irremediavelmente encobertos. Não pretendo, com isto, dizer que esta teria sido uma prática corriqueira ou mesmo comum naquela sociedade. Com certeza, não deveria ser muito fácil às cativas esconderem suas gravidezes de seus senhores. Por outro lado, Josefa não deve ter sido a primeira mãe escrava a procurar garantir a liberdade de seu filho por este meio. Pode-se conjecturar que, especialmente na Vila, onde a escravidão ao ganho possibilitava a cativos "viverem sobre si", histórias como estas, com um desfecho distinto podem ter ocorrido. E as crianças, talvez, tenham podido viver - apesar da pigmentação de suas peles - como "brancos".

Ainda em relação à "cor" dos enjeitados, Renato Pinto Venâncio chama a atenção para mudanças ocorridas entre o século XVIII e o XIX. Os dados apresentados pelo autor indicam que, enquanto, na segunda metade do século XVIII, a maior parte das crianças expostas na Roda de Salvador era branca, progressivamente a tendência foi-se invertendo e, a partir de 1850, os negros e os mestiços já constituíam a maioria dos recebidos pela instituição. Também no Rio de Janeiro teria havido redução "no número de enjeitados de pele alva" 28 .

Quando se observam os dados relativos a São João del Rei ao longo do período, constata-se que a grande maioria dos registros que indicaram a cor dos expostos fora feita no século XIX. Dos 44 assentos de crianças mencionadas como brancas, apenas quatro foram feitos no século XVIII, todos no ano de 1765 . Os 40 restantes datam do período posterior a 1813. O único registro de criança preta exposta foi escrito em 1815. Dos 42 
assentos relativos a crianças pardas, mulatas ou cabras, 34 foram redigidos depois de 1813. Parece-me claro que foram os párocos dos oitocentos os que mais preocupação tiveram em registrar este atributo dos enjeitados.

$\mathrm{Na}$ análise dos dados apresentados por Venâncio ${ }^{29}$, sobretudo para Salvador, percebe-se que é a segunda metade do século XIX que marca um declínio efetivo no índice de exposição de crianças brancas, em comparação com as negras e as mestiças: de 51,5\% que as brancas representavam, entre 1801 e 1850 , passam a constituir 16,9\%, entre 1851 e 1870 . Creio que as explicações para esta tendência se encontram ligadas ao contexto de crise do escravismo, quando talvez maior atenção fosse dada a tentativas de "libertação" de cativos através da exposição. Embora não possa apresentar argumentos mais sólidos neste sentido, parece-me mais plausível que as alterações correspondam principalmente a uma mudança de atitude por parte dos que registravam a "cor" das crianças - párocos ou funcionários da Santa Casa - do que efetivamente a uma diminuição proporcional da exposição de criança por parte dos progenitores de "pele alva".

Outro ponto, argumentado por Sheila de Castro Faria, que deve ser matizado, diz respeito à vinculação direta entre ascendência cativa e pobreza. A própria autora, em pesquisa recente, tem indicado a relativa prosperidade econômica alcançada pelas mulheres forras ${ }^{30}$. Por outro lado, como afirma Venâncio, mesmo aceitando ser "grande a probabilidade de a maioria dos abandonados originar-se de famílias brancas", há que se considerar que a pobreza não esteve ausente do "mundo dos brancos"31.

$\mathrm{O}$ autor, analisando os diversos argumentos presentes na historiografia para explicar o fenômeno da exposição, afirma a inutilidade da busca de origens únicas. Acredita, porém, ser possível avaliar, pela demografia histórica, "o principal motivo que levava as famílias a procurar a Roda"32. Conclui que, apesar da possibilidade de mulheres brancas de elite abandonarem seus filhos por razões morais, estes casos não teriam sido dominantes. Segundo sua argumentação, se houvesse um predomínio de filhos ilegítimos entre os expostos deixados nas Rodas, o normal seria que o aumento dos índices de exposição fosse acompanhado por um declínio da ilegitimidade. Seus dados, porém, não indicam esta relação. Tampouco os dados relativos a São João del Rei caminham neste sentido, como se pode observar na Tabela 2. 
Tabela 2 - Legitimidade dos Filhos de Mães Livres, por décadas

\begin{tabular}{|c|cc|cc|cc|cc|}
\hline $\begin{array}{c}\text { Legitimidade } \\
\text { Período }\end{array}$ & \multicolumn{2}{|c|}{ Legítimo } & \multicolumn{2}{c|}{ Ilegítimo } & \multicolumn{2}{c|}{ Exposto* } & \multicolumn{2}{c|}{ Total } \\
\hline $1736-1740$ & 74 & $77,89 \%$ & 16 & $16,84 \%$ & 5 & $5,26 \%$ & 95 & $100 \%$ \\
$1741-1750$ & 138 & $74,59 \%$ & 32 & $17,30 \%$ & 15 & $8,11 \%$ & 185 & $100 \%$ \\
$1751-1760$ & 60 & $81,08 \%$ & 11 & $14,86 \%$ & 3 & $4,06 \%$ & 74 & $100 \%$ \\
$1761-1770$ & 249 & $64,85 \%$ & 72 & $18,75 \%$ & 63 & $16,40 \%$ & 384 & $100 \%$ \\
$1771-1780$ & 139 & $63,76 \%$ & 49 & $22,48 \%$ & 30 & $13,76 \%$ & 218 & $100 \%$ \\
$1781-1790$ & 445 & $55,55 \%$ & 186 & $23,22 \%$ & 70 & $21,23 \%$ & 801 & $100 \%$ \\
$1791-1800$ & 484 & $54,44 \%$ & 217 & $24,41 \%$ & 188 & $21,15 \%$ & 889 & $100 \%$ \\
$1801-1810$ & 340 & $50,75 \%$ & 197 & $29,40 \%$ & 133 & $19,85 \%$ & 670 & $100 \%$ \\
$1811-1820$ & 535 & $55,44 \%$ & 238 & $24,66 \%$ & 192 & $19,90 \%$ & 965 & $100 \%$ \\
$1821-1830$ & 740 & $61,98 \%$ & 314 & $26,30 \%$ & 140 & $11,72 \%$ & 1194 & $100 \%$ \\
$1831-1840$ & 709 & $65,65 \%$ & 314 & $29,07 \%$ & 57 & $5,28 \%$ & 1080 & $100 \%$ \\
$1841-1850$ & 868 & $69,83 \%$ & 336 & $27,03 \%$ & 39 & $3,14 \%$ & 1243 & $100 \%$ \\
\hline
\end{tabular}

Fonte: MNSP-SJDR. Registros Paroquiais de Batismo, 1736-1850.

* No caso dos expostos, estou considerando a condição das pessoas que receberam as crianças em suas casas.

No entanto, muitos filhos ilegítimos, mencionados em inventários e testamentos, haviam sido expostos por seus progenitores.

Por outro lado, Venâncio constata - a partir da análise das variaçóes de preços, sobretudo para o Rio de Janeiro, e das oscilações dos óbitos de pobres - uma relação direta entre abandono de crianças e pobreza. Em suas palavras,

No Brasil antigo, o abandono de crianças dizia respeito aos pobres, mas não a todos os pobres indiscriminadamente. A maioria das famílias humildes resistia a enviar o filho à Roda. Contudo, por ocasião da morte de parentes próximos, essa decisão não podia ser protelada ${ }^{33}$.

É uma conclusão cautelosa: a pobreza estaria na origem dos enjeitamentos, mas nem toda pobreza levava à exposição. Isto ocorria quando a ela se associava uma "crise familiar", nos casos mais graves, ligada à morte de um dos progenitores, mas que também podia relacionar-se a outros problemas, como, por exemplo, doenças dos pais ou das crianças. 
Embora o autor tenda, portanto, a associar o abandono mais à pobreza do que a fatores de ordem moral para as elites, parece-me difícil dimensionar a influência que os dois aspectos poderiam ter sobre o fenômeno da exposição. Afinal, também se poderia dizer que, embora nem toda prole ilícita das elites tivesse como destino o enjeitamento, aquela, cujos pais passassem por alguma circunstância específica, o teria. A ausência de queda nos índices de ilegitimidade, por ocasião da elevação dos de exposição, poderia ser interpretada de modo distinto. É plausível supor que o aumento da ilegitimidade em determinados períodos fosse maior, caso não houvesse o recurso ao abandono dos filhos não desejados. Assim, os fatores que estimulariam o aumento da ilegitimidade atuariam no mesmo sentido provocando o crescimento dos enjeitamentos.

Nos casos de expostos originários da elite e abandonados por motivos de ordem moral, a natureza dos problemas enfrentados pelos progenitores seria distinta da dos pobres que enjeitavam seus filhos, mas ainda assim não deve ser desconsiderada. Poderia estar associada a um casamento próximo, como foi o caso, por exemplo, de Tereza, batizada em 30 de agosto de 1766, como exposta em casa do Tenente João da Costa Vale. Em nove de setembro de 1767, seus pais biológicos, o Capitão José Cabral Tavares e Dona Maria Josefa Ferreira, se casaram, reconhecendo-a posteriormente como filha ${ }^{34}$.

João Basílio dos Santos foi batizado em 14 de junho de 1824, como exposto a Dona Domingas Maria Duarte ${ }^{35}$. Seus pais biológicos, Crispiniano Antonio dos Santos e Mariana Cândida dos Santos, se casaram em 28 de junho de 1826. Detalhe interessante, nesta história, é que também Crispiniano era exposto. Assim, pode-se perceber que este tipo de estratégia de ocultamento da paternidade, em alguns casos, podia ser repetido pelas gerações, indício de que a exposição tivesse, talvez, mesmo para os que eram enjeitados, um significado distinto do que hoje assume o abandono de filhos. A situação parecia ser encarada com mais tranqüilidade naquela sociedade. Os filhos não se sentiriam necessariamente menosprezados pelos pais biológicos, pelo fato de terem sido expostos. A diversidade de fatores que podia levar a esta situação parecia fazê-la mais aceitável socialmente e mesmo pelos próprios expostos, nem sempre privados do conhecimento e do convívio com seus progenitores. 
Não só mulheres ou casais ocultavam suas proles através da exposição. Anastácio José de Sousa, depois de ficar viúvo em 1793, teve uma filha natural chamada Maria, que foi batizada como exposta e criada em sua casa. $\mathrm{O}$ reconhecimento da paternidade foi feito em seu testamento, datado de 7 de abril de $1805^{36}$.

A preocupação com questôes de ordem moral poderia levar não só à exposição com o objetivo de encobrir a prova da "fragilidade humana", mas também à ausência de menção ao fato, depois de passados muitos anos. O Capitão José Gomes da Costa redigiu seu testamento em junho de 1827, arrolando nove filhos tidos com sua esposa Maria Hilária da Silva. Inicialmente, tender-se-ia a considerar toda a prole como legítima, no entanto, Maria Hilária, em testamento redigido em abril de 1825 , esclarece que

(...) vivendo no estado de solteira, nele tive vários filhos, que por recato e decência se batizaram por expostos e vem a ser: Narciso José da Costa já falecido (...), Rosa Maria de Jesus (...), José Joaquim da Costa, Joaquim José da Costa, João Evangelista da Costa, Antonio Joaquim da Costa, Felisberta casada com José Joaquim Pimenta, todos estes filhos havidos do Capitão José Gomes da Costa, com quem ao depois me casei (...). Declaro que ao depois do meu casamento com o dito Capitão José Gomes, deste matrimônio tive uma única filha de nome Ponciana Maria de Jesus (...) [grifo meu] ${ }^{37}$.

A ausência de menção ao fato, no testamento do Capitão José Gomes, pode ser explicada por ter o casamento efetivamente legitimado a prole havida antes de sua celebração. Este matrimônio deve ter sido contraído entre 1798 e 1803, ano do nascimento da filha legítima do casal, Ponciana. De qualquer forma, a declaração de Maria Hilária permite perceber que a exposição de crianças, frutos de relações não sancionadas pela Igreja, não era uma estratégia esporádica. Em casos como o desta família, pode-se notar que era prática deliberada e recorrente: foram oito os filhos expostos em fins do século XVIII!

Outra mãe a adotar sucessivamente a exposição de filhos, que poderiam revelar seus "deslizes morais", foi Germana Nunes Maurícia. No estado de solteira, teve seis filhos, todos batizados como expostos. Apesar de tê-los posteriormente reconhecido publicamente como filhos, não che- 
gou a fazê-lo em nenhum documento, por isto tiveram que entrar com um processo para se habilitarem como seus herdeiros. Foi através deste documento, anexado ao inventário de Germana, que sua história pôde ser revelada:

(...) achando-se a mesma D. Germana Nunes ainda antes do ano de 1819 vivendo em companhia de sua irmã D. Bernarda Graciana de Magalhães, casada com o Tenente Coronel José Coelho Mendes, contudo e não obstante o recato em que se achava, teve de dar a luz o primeiro justificante Francisco seu filho e para encobrir sua fraqueza foi este exposto em casa do Tenente Francisco Correa Nunes, seguindo-se depois ter mais os filhos seguintes: os justificantes D. Maria e D. Elisa que foram também expostos na casa do dito Nunes e a D. Genoveva Maximiana das Dores (...) .

(...) mudando-se a mãe dos justificantes, no ano de 1823 , para a sua própria casa, sita na Rua do Curral desta cidade, aí teve mais os filhos seguintes: a justificante D. Josefina que foi exposta a Maria Gonçalves, a justificante D. Eulina e Antonio Francisco Coelho, sendo estes dois últimos expostos na própria casa de sua mesma mãe D. Germana (...)

(...) a mãe dos justificantes, tendo no ano de 1834 junto ali e em sua companhia todos os justificantes seus filhos, daí em diante até a sua morte, que foi repentina, os reconheceu como tais, dando-lhes boa educação, declarando a pessoas que iam à sua casa que todos os justificantes eram seus filhos naturais e seus únicos herdeiros (....) [grifos meus] $]^{38}$.

É possível que, enquanto morava em casa de sua irmã, Dona Germana não tivesse condiçôes econômicas próprias que lhe permitissem assumir a criação dos filhos, no entanto, há que se considerar que questóes de ordem moral parecem ter tido também um peso importante em sua decisão, afinal, tanto na petição dos filhos, quanto nos depoimentos das testemunhas, são constantes as afirmações de que ela vivia "com recato", mas que, ainda assim, engravidara. A exposição visava, pois, "encobrir sua fraqueza”. Pode-se supor que seu cunhado, o Tenente-Coronel José Coelho Mendes, não quisesse manchar a reputação familiar com a prole ilegítima de Germana, que, à época em que nascera o primeiro filho, tinha por volta de 17 anos. Pela sua menoridade, é possível que a irmã ou seu cunhado fossem seus tutores. Foi apenas em 1823, quando Germana tinha cerca de 21 anos, que se mudou para sua própria casa. Talvez tenha sido emancipa- 
da e recebido alguma herança, até então administrada pelos tutores, o que lhe teria permitido estabelecer-se sobre si mesma ${ }^{39}$. De qualquer forma, a maior autonomia não a impediu de continuar a expor seus filhos. Em 1827, expôs Josefina a Maria Gonçalves. Em 1833, enjeitou a si mesma os gêmeos Eulina e Antonio. Já no ano seguinte, assumia a todos como seus filhos. É interessante também observar que, nos anos de 1829 e 1831, foram batizados dois meninos, José e João, expostos em casa de Germana Nunes Maurícia. Os intervalos entre os nascimentos podem sugerir que estas crianças também fossem seus filhos, mas que teriam morrido antes da mãe, não aparecendo, por isto, em seu inventário.

O depoimento de pessoas que ajudaram Germana, no processo de exposição dos filhos, esclarece alguns pontos. Dona Genoveva Maximiana das Dores, amiga de Germana, recebera os seus três primeiros filhos, todos criados em casa do Tenente Francisco Correa Nunes, onde era moradora. Afirmou que "Dona Germana, pela sua própria mão e com algum segredo, é quem deu a ela testemunha os enxovais para os ditos seus três filhos $(. . .)^{40 "}$.

Infelizmente, não se sabe de que se compunham estes enxovais, mas é digno de nota o fato de que a mãe dispunha de recursos para adquiri-los. Também Joana Maria da Conceição, crioula livre, esteve presente por ocasião do nascimento dos três primeiros filhos de Germana. Segundo seu depoimento, a própria mãe a havia escolhido para ama-de-leite das crianças, criadas em casa do Tenente Francisco Correa Nunes. Se a mãe escolheu até mesmo a ama dos filhos, cabe perguntar se não seria ela a responsável pelo pagamento do serviço. Dificilmente uma resposta definitiva a esta questão poderá ser encontrada, mas deve-se lembrar que as próprias Ordenaçôes Filipinas estabeleciam a obrigação dos progenitores, mesmo de filhos naturais, de alimentarem e criarem sua prole ${ }^{41}$. Afinal, teria a mãe condições de escolher a ama de seus filhos, se fossem os donos da casa onde a criança fora enjeitada os responsáveis pelo seu pagamento? Por outro lado, aceitar que era Germana quem arcava com as despesas afasta a hipótese de falta de recursos para a criação dos filhos e reforça a tese dos entraves de ordem moral para que assumisse a maternidade. Além disto, o argumento ganha força também pelo fato de os últimos filhos terem sido expostos à própria mãe. Neste caso, não consigo imaginar outro fator que o justifique senão os ligados "ao recato e à decência". 
Outro dado interessante na história de Germana diz respeito a ter ela, ao que tudo indica, acompanhado a criação de seus filhos. Não se tratava simplesmente de um abandono. Tanto assim que, em 1834, pôde reuni-los todos em sua companhia, sendo mencionados, na lista nominativa feita na Vila de São João del Rei, em 1838, como filhos, no fogo por ela chefiado.

A possibilidade de acompanhamento da criação de filhos enjeitados passava primeiramente pela escolha das pessoas que receberiam as crianças. No caso de Germana, pode-se perceber que a amizade com Dona Genoveva Maximiana das Dores fez com que três de seus filhos fossem enjeitados na casa em que esta morava. Algumas informações sobre as pessoas que recebiam as crianças expostas podem ajudar a pensar a motivação de seus progenitores ao enjeitá-las.

Do total de crianças expostas, cujos nomes dos que as receberam puderam ser identificados nas atas de batismo, 1.152 (54,6\%) foram enjeitadas a homens e 946 (44,9\%), a mulheres. Além destes, três crianças foram batizadas como expostas à Santa Casa de Misericórdia, mesmo em época em que não havia Roda na instituição, e oito à Câmara Municipal. Também Carlos Bacellar encontrou para Sorocaba, entre 1679 e 1830, um predomínio de exposição em fogos de chefia masculina (65,8\% contra 34,2\% chefiados por mulheres) ${ }^{42}$. Nenhuma correspondência pode ser observada entre os sexos das crianças e dos que as recebiam: 46,5\% (495) das meninas e 43,2\% (451) dos meninos foram enjeitados a mulheres. A diferença percentual é muito pequena para sugerir qualquer preferência neste sentido.

Quanto ao estado conjugal das pessoas que recebiam as crianças, em apenas 331 casos foi informado. Destes, 184 (55,6\%) eram casados, 71 $(21,4 \%)$ viúvos e $76(23,0 \%)$ solteiros. O cruzamento desta variável com o sexo do recebedor das crianças é bastante elucidativo: dentre os solteiros, 24 (31,6\%) eram homens e $52(68,4 \%)$ mulheres. Já entre os casados, cujos sexos puderam ser identificados, $165(91,7 \%)$ eram homens e $15(8,3 \%)$ mulheres. Os dados explicitam que, se havia um predomínio masculino entre os recebedores de expostos, em seus domicílios havia mulheres capazes de se ocuparem do cuidado das crianças. No próprio caso de Germana Nunes Maurícia, pode-se perceber como, ao enjeitar seus três primeiros filhos em casa do Tenente Francisco Correa Nunes, pretendia contar com os 
cuidados da amiga Genoveva Maximiana das Dores, que residia no domicílio dele.

Em relação à condição social dos que recebiam enjeitados, predominavam obviamente os livres (1969 casos, ou 90,7\%). Os forros constituíam 9,2\% deste universo, recebendo 199 crianças, e dois escravos também receberam enjeitados $(0,1 \%)$. Chama a atenção o fato de que, entre os forros, a grande maioria era de mulheres, 149 casos contra 43 homens. É claro que esta tendência refletia, por um lado, o predomínio feminino entre a população liberta, mas, para além disto, creio ser importante considerar a relativa prosperidade alcançada pelas forras, sobretudo através do comércio de tabuleiros, conforme tem sido indicado por Sheila de Castro Faria. Não acredito que filhos da elite branca fossem prioritariamente enjeitados a mulheres forras, mas seria, provavelmente, em seus fogos que as crianças, filhas de pessoas menos favorecidas socialmente, encontrariam melhores condições de sobreviver. É possível que em domicílios de "brancos", crianças "mestiças" fossem incorporadas mais como agregados do que como parte efetiva da família. Já nos lares de forras, talvez pudessem gozar de um status diferente. A hipótese me parece bastante plausível, sobretudo em se considerando o fato de terem as libertas poucos filhos ${ }^{43}$, o que as tornaria, possivelmente, mais receptivas àquelas crianças $^{44}$, criando com elas laços de maior proximidade e, quem sabe, podendo beneficiá-las, tanto em vida quanto em legados testamentários. É interessante observar, por exemplo, o fato, indicado por Sheila de Castro Faria, de as forras proprietárias de cativos, em geral, alforriarem os filhos - aliás, sobretudo as filhas de suas escravas ${ }^{45}$.

Outro aspecto importante na caracterização dos recebedores de expostos é a sua idade. Infelizmente, os registros paroquiais de batismo não trazem este tipo de informação, inviabilizando, pois, uma análise em bases quantitativas mais extensas. No entanto, a montagem de algumas fichas de famílias, com cruzamento de fontes, permite que certas tendências sejam indicadas, ainda que, quantitativamente, não sejam muito expressivas.

Uma primeira tendência observada foi a exposição a mulheres que estavam ainda dentro de seu período fértil, ou seja, que foram encontradas batizando filhos no mesmo período em que receberam as crianças 
expostas. Nesta situação encontrei sete fichas de famílias, totalizando 13 enjeitados. As mulheres eram principalmente solteiras (cinco delas) e forras (seis). Bernarda Maria Pereira, crioula forra, solteira, foi a que mais expostos recebeu nesta situação: cinco crianças, batizadas entre 1788 e 1803. Dentro do período, em 21 de fevereiro de 1800 foi batizada Violante, filha natural de Bernarda. Floriana Antonia Sousa, preta mina, forra e solteira, teve três filhos naturais, entre 1801 e 1809. Em 1803 e 1804, foram batizadas duas meninas expostas em sua casa. A parda forra Efigênia Maria Silva teve três filhos naturais, entre 1780 e 1811. Em 1791, foi batizada Floriana, exposta em sua casa. Joana Batista da Visitação, crioula forra, solteira, teve três filhos naturais, entre 1807 e 1824. Em 1816, foi batizada a exposta Maria, deixada em sua casa. Jacinta Rosa São José, parda forra, quando se casou, em 1813 , já possuía cinco filhos naturais, tidos entre 1803 e 1813 . O último era filho do homem que se tornou, apenas dois meses depois do nascimento da criança, seu marido, Miguel Joaquim Santana. Depois de casada, teve ainda mais dois filhos legítimos, em 1817 e 1824. Ainda quando solteira, porém, no ano de 1811 , recebera em sua casa a exposta Claudina.

Leonor Teixeira Conceição foi outra forra a receber um exposto em sua casa, quando ainda estava em seu período fértil. Marcelino foi batizado em 1789. Diferente de suas companheiras descritas acima, porém, Leonor era casada, quando recebeu o enjeitado, no entanto, ao que parece, não fazia vida marital com seu esposo. Dois de seus filhos, batizados em 1780 e 1783, foram caracterizados como filhos naturais de mãe casada, e outros dois, batizados em 1787 e 1796, simplesmente como filhos naturais.

Expor filhos a mulheres ainda em seu período fértil, no mais das vezes em momentos próximos a partos, pode ser indício da busca pela garantia de aleitamento às crianças. Sem dúvida, um dado importante para garantirlhes a sobrevivência. É interessante, porém, o predomínio de mulheres forras e solteiras neste universo. Seriam elas as mais propensas à prática da amamentação?

Uma outra tendência observada na escolha dos recebedores das crianças era a preferência por pessoas mais velhas, sobretudo mulheres. Ana 
Francisca Rodrigues recebeu três expostos em sua casa, nos anos de 1803 e 1804, tendo, respectivamente, 59 e 61 anos completos. Seu marido havia falecido em 1797. Em 1803, seu filho mais novo teria de idade 28 anos.

Juliana Albina Bitencourt, mulher branca e solteira, recebeu uma exposta, em 1803, quando teria 43 anos. Em 1819, foram-lhe enjeitados mais dois meninos, tendo, então, 59 anos. Em 1838, por ocasião da elaboração da lista nominativa na Vila de São João del Rei, Juliana morava no fogo chefiado pelo Vigário José Francisco Lopes, onde também residia Alexandre Ribeiro Resende, um dos que tinham sido expostos em 1819.

Para outras pessoas não é possível precisar idades, mas imagino que não seriam muito jovens, em função de algumas informações indiretas. Margarida Joaquina Guerra, ao receber a exposta Maria, em 1809, era viúva e viria a morrer apenas três anos depois. Maria Fernandes de São José recebeu a exposta Ana, em 1826, quatro anos antes de sua morte e 26 anos depois do nascimento de seu filho mais novo.

Em mais sete fichas de famílias, mulheres viúvas constam como recebedoras de enjeitados, totalizando 16 crianças. Outras sete receberam crianças expostas vários anos após o nascimento de seus últimos filhos. Neste caso, encontravam-se 14 crianças. Os intervalos entre os nascimentos e a exposição variaram de sete a vinte e sete anos. Os dados parecem indicar a idade avançada destas mulheres ao receberem os expostos. A questão que fica é saber por que eram escolhidas pelas mães.

Uma primeira hipótese poderia relacionar-se à própria proximidade da morte destas mulheres. Talvez as mães das crianças imaginassem que teriam mais dificuldade em recusar não apenas a criação, mas mesmo bons tratos a seus filhos, com temor de condenações no além-túmulo. Outra possibilidade, diretamente ligada a esta, seria a costumeira prática de se deixarem legados em testamentos a crianças expostas. Embora nem todos os enjeitados agraciados fossem criados pelos testadores, a proximidade cotidiana e o afeto que entre eles podia desenvolver-se possivelmente lhes facilitaria alguns ganhos.

Encontrei dezessete testamentos nos quais se deixavam legados a expostos. Destes, doze foram feitos a crianças criadas na casa dos testadores e apenas cinco a enjeitados a outras pessoas. Antonio Ferreira Rocha, por exemplo, deixava "à minha exposta Beralda pela ter criado 50\$000, caso 
que viva honestamente a ocasião de se casar o meu testamenteiro lhe assistirá com aquilo que for necessário" 46 . Antonio Gonçalves Penha estabeleceu, em seu testamento, que se "dará a um enjeitado criado em minha casa, por nome Francisco, 150\$000”47. Felícia Barbosa da Silveira registrou em seu testamento que

(...) os sobrados em que eu moro, sito na Rua da Intendência, em cima pertencem dois quartos pela banda da estalagem a uma menina enjeitada, por nome Maria Bárbara, que a criei em minha casa e se acha em minha companhia e da minha escada com seus fundos em diante pertence à mesma menina Maria Bárbara, da escada para a rua pertence a José Antonio da Silveira, que foi dádiva da defunta minha irmã Rita que lhe fez em sua vida. (...) Declaro que também deixo à minha enjeitada Maria Bárbara o meu oratório e imagens e a cômoda aonde está o oratório, com a condição de mandar dizer quatro missas por minha alma, de que apresentará certidão a meu testamenteiro ${ }^{48}$.

Dona Ana Francisca Rodrigues, que morreu em 1808, deixou, em seu testamento, 16 oitavas de ouro a cada uma de duas meninas que havia criado em sua casa ${ }^{49}$. Seu marido, Dionisio Gonçalves Pedreira, que falecera em 1797, já havia deixado, em seu testamento, vinte oitavas de ouro a cada uma ${ }^{50}$. Os expostos a casais podiam, pois, beneficiar-se com mais de um legado. O casal do Capitão José Gomes da Costa e Maria Hilária da Silva - que havia enjeitado seus sete filhos, nascidos antes de se casarem - também criou crianças expostas em sua casa e não deixou de beneficiálas. No testamento do Capitão, assim se manifestou:

Ordeno a meu testamenteiro que conservará na minha fazenda a meu enjeitado e afilhado Manoel de Bela Cruz, o qual terá o uso fruto da mesma conjuntamente com os meus filhos, para fazer suas pequenas plantações, de acordo com os mesmos para não causar prejuízos, cujas plantaçôes não serão excessivas e somente quanto lhe baste para poder viver, e não poderá meter agregados porque este benefício se deve entender unicamente a seu respeito $^{51}$.

O menino foi ainda beneficiado no testamento de Maria Hilária:

Deixo a meu afilhado e sobrinho Manoel José da Bela Cruz, que foi meu exposto, outra tanta quantia que liquidamente tocar a cada um de meus 
filhos, depois de pagas as dívidas de meu casal, e houverem de pertencerlhes da minha herança materna, cuja quantia se imputará da minha terça, e não havendo dinheiro se lhe pague em bens ${ }^{52}$.

Tamanho benefício se justificava, provavelmente, não só pela criação, mas pelo parentesco consangüíneo e espiritual reconhecido por Maria Hilária, que, além do mais, indica o conhecimento da origem da criança. Outra criança criada nesta casa foi lembrada apenas pelo marido: José Joaquim da Costa, filho de Ana de Tal, não foi caracterizado como exposto, mas instituído herdeiro de parte dos bens da terça do Capitão José Gomes da Costa, em função de este tê-lo criado.

A preta mina forra, Maria de Almeida, que morreu solteira sem deixar filhos, deixou à sua enjeitada Ana Maria 20\$000 e a Antonio Lino, criado por ela, $10 \$ 000^{53}$. Inácia Teodora de Jesus, que também morreu solteira e sem descendentes, estabeleceu como sua universal herdeira uma menina, sua enjeitada, chamada Maria, que, por ocasião da redação do testamento, em 1820, tinha sete anos de idade ${ }^{54}$. Ana Maria de Moura foi outra mulher solteira a morrer sem herdeiros forçados. Em seu testamento, determinou

Para meus universais herdeiros, em igual parte, ao meu primo e testamenteiro, o Furriel Francisco Joaquim Teixeira, em atenção à boa companhia que me tem feito, e a três enjeitados que estão comigo, Maria Batista e Maria Francisca e José Maria, pelo amor em que os criei, sem prejuízo um de outro, todos em igual parte no líquido de meus bens $(. . .)^{55}$.

No testamento, observa-se a explicitação do sentimento que ligava as crianças a quem as havia criado. Isto também pode ser notado no testamento de Cipriana Marcelina da Conceição - que também morreu solteira e sem filhos. Assim se manifestou:

Instituo e declaro por meus universais herdeiros de todos os meus bens à dita minha primeira testamenteira, Maria Perpétua da Conceição, e a cinco meninos expostos José, Teresa, João, Francisco e Carlos, todos de inferior idade e assistentes em minha casa, que partirão esses poucos bens que acharem amigavelmente entre si, sem que seja preciso fazer inventário, recompensando-lhes assim o grande amor que sempre me tiveram e o muito que me correram nas minhas necessidades ${ }^{56}$. 
$\mathrm{Na}$ citação, além da referência ao "grande amor" que ligava Cipriana aos expostos que criara, observa-se um dado importante para se tentar entender os enjeitamentos, principalmente, aos mais velhos. Trata-se da possibilidade de o sentido da solidariedade ser diferente do normalmente apontado pela historiografia, ou seja, nem sempre seriam os criadores das crianças a auxiliarem seus pais biológicos. É possível que, ao enjeitar uma criança a alguém, o objetivo fosse também o de prestar auxílio à pessoa que a recebia, afinal, o exposto poderia "correr-lhe" em suas "necessidades". A este respeito, Bacellar considera que seria mais prático aos recebedores dos expostos, principalmente os mais velhos, recorrerem a agregados adultos, do que esperarem que os enjeitados chegassem à idade produtiva ${ }^{57}$. Deve-se considerar, porém, que as "necessidades" que poderiam ter estas pessoas não se restringiriam necessariamente à questão da mão-de-obra. Poderiam remeter à outra ordem de fatores, inclusive afetivos. Poderia ser este o caso, por exemplo, de José Francisco da Silva e de Maria Joaquina Assunção, que tinham, em 1832, respectivamente, 66 e 61 anos. No fogo do casal, chefiado por José Francisco, moravam dois expostos, um rapaz de 19 anos e uma menina, de 9 . No entanto, o casal não parecia depender do trabalho destes enjeitados para sua sobrevivência, na medida em que possuíam 27 cativos. Poucos foram os expostos arrolados, na lista nominativa feita para São João del Rei, na década de 1830. A maioria não deve ter sido identificada como tal, mas, dos poucos expostos listados, muitos estavam em domicílios com cativos ${ }^{58}$. Os que recebiam crianças, sobretudo os mais velhos, pareciam não precisar do seu trabalho, mas talvez necessitassem de sua companhia, atenção e carinho.

Nos testamentos em que são deixados legados a expostos, criados por pessoas que não os testadores, alguns apresentam indícios de filiação. $\mathrm{O}$ Capitão Antonio José Moreira - que se casou três vezes e ao morrer tinha duas filhas como herdeiras - em seu testamento deixou "300\$000 de esmola a uma moça que foi criada em São João del Rei, em casa do Capitão Antonio José Pacheco, a qual se acha casada para as partes do Japão, cuja pessoa o meu primeiro testamenteiro sabe quem seja" ${ }^{59}$. Tantas informações sobre a moça e, ao mesmo tempo, a omissão do seu nome parecem indicar o desejo de beneficiá-la, mas sem que maiores dados fossem forne- 
cidos. É plausível supor que fosse sua filha, mas que ele não quisesse reconhecê-la como tal.

O Capitão Tomás Carlos de Sousa, que, ao morrer, deixou quatro filhos legítimos, instituiu “(...) por minha herdeira de todo o remanescente de minha terça a Teresa Claudina de Sousa, que se acha hoje em minha casa, e foi exposta em casa do Tenente Bonifácio Gonçalves de Aguiar ${ }^{60}$ ".

Se não é possível comprovar a hipótese de filiação, não parece absurdo levantá-la. Tal possibilidade talvez fosse mesmo aventada pelos contemporâneos, ao verem expostos beneficiados por pessoas que não os haviam criado. Isto pode ter passado pela cabeça de Marcelino Rodrigues Aquino, ao redigir seu testamento, em 1836. Depois de deixar 50\$000 de legado a cada uma de duas expostas, criadas em casas de terceiros, declara

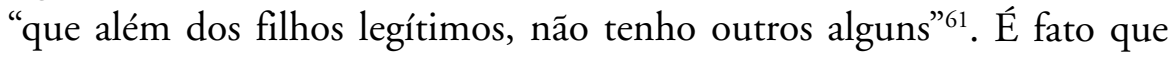
outros níveis de proximidade ou parentesco também poderiam justificar semelhantes doaçôes. Seria o caso de Jerônimo Sousa Ferras, que morreu solteiro e sem filhos, em 1813. Em seu testamento, estabeleceu:

Deixo à minha afilhadinha Carlota, exposta em casa de minha cunhada e testamenteira dita Dona Matilde, um potrinho lazão que se está criando e mais $50 \$ 000$, que tudo administrará a minha mesma cunhada, sua madrinha, para dispor em utilidade da mesma menina, pois que lhe quero muito bem ${ }^{62}$.

Neste caso, seria o parentesco espiritual do compadrio, provavelmente, o elo mais forte a aproximar o testador da exposta. Em todos estes casos, porém, fica patente que, mesmo que nem sempre os beneficiados fossem criados pelos legatários, era mais fácil aos enjeitados da casa do testador receberem benefícios e isso poderia ser considerado pelas mães na escolha de pessoas mais velhas para cuidar de seus filhos.

Outro ponto a ser aventado na escolha, pelas mães, de quem receberia seus filhos, diz respeito à proximidade que entre eles haveria. Em vários exemplos descritos acima, observa-se um acompanhamento da mãe em relação à criação dos filhos expostos. Em alguns, o "abandono" foi inclusive momentâneo, com o posterior retorno das crianças para a companhia da mãe ${ }^{63}$. Ora, esta possibilidade era facilitada pelo conhecimento e pela familiaridade entre os progenitores e os que recebiam as crianças. Sheila de Castro Faria ${ }^{64}$ indicou, em sua pesquisa para Campos dos 
Goitacazes, a possibilidade de parentes estarem entre os principais recebedores de expostos. Já vimos que o casal do Capitão José Gomes da Costa e Maria Hilária da Silva criou o sobrinho Manoel da Bela Cruz. Mariana Bernarda de Sousa foi exposta ao Alferes Antônio Rodrigues Melo, cunhado de sua mãe, Dona Ana Bernardina de Sousa. Nestes casos, ao que tudo indica, a família funcionava como um importante apoio aos que enjeitavam seus filhos. Percebe-se que, mesmo quando se tratava de encobrir gestações e partos indesejáveis, as teias familiares se faziam importantes, afinal, no mais das vezes, não se tratava apenas de encobrir deslizes morais pessoais, mas sim de garantir o sucesso de estratégias familiares. Como diz Sheila de Castro Faria,

Deve-se ressaltar que a exposição de crianças representava a própria manutenção da estabilidade familiar ou, melhor dizendo, da moralidade familiar. Para os mais ricos, esconder filhos naturais ou adulterinos poderia significar manter a herança dentro da legalidade e da moral católica. Abandonar os filhos indesejáveis permitia às pessoas solteiras voltarem sem empecilhos ao mercado matrimonial. Acho pouco provável que [...] casais pobres tenham exposto seus filhos, mão-de-obra que se tornariam adiante. Já as mães solteiras teriam, quando pobres, talvez mais necessidade de fazê-lo, mas mesmo assim acho que a origem do enjeitado, independentemente da fortuna dos pais, está relacionada com uma gravidez indesejada, não prevista. Em suma, mesmo que a exposição de crianças possa ter-se dado por motivos econômico-financeiros ou morais, o que se pretendia era manter a unidade produtiva familiar em funcionamento, fosse pobre ou rica, dentro do que se pensava serem as condições mínimas favoráveis ${ }^{65}$.

Neste sentido, a exposição de crianças era também um projeto familiar, no qual as solidariedades, calcadas no parentesco, se manifestavam. De modo especial, nestes casos, é lícito supor que a filiação das crianças era muito mais conhecida do que se poderia supor inicialmente.

\section{Inserção Social dos Expostos}

Felisarda Matilde de Morais Salgado foi batizada, em 20 de outubro de 1755, como exposta a Francisco Marques das Neves. Em seu testamento, porém, redigido em 1812, declara ter sido exposta em casa do Padre João Gomes Salgado. Talvez, algum tempo depois do batismo, tenha pas- 
sado aos cuidados do religioso. Em 1789 - sendo já viúva do SargentoMor João Silva Ribeiro de Queirós - era apregoada para se casar com o Capitão Domingos Rodrigues Barreiros. No decorrer do processo matrimonial, alguns aspectos sobre a exposição de Felisarda são esclarecidos. Eles pediram dispensa do impedimento de segundo grau de afinidade, misto com o primeiro, em função de ser a mãe da noiva, Bernarda Maria da Conceição, irmã do Capitão Domingos. Em sua petição, explicaram as circunstâncias da exposição de Felisarda:

(...) Bernarda Maria da Conceição foi casada com Felipe da Silveira, e declarando-se a este a moléstia morféia, de que veio a morrer, eles se separaram logo quad torum, e durante a separação teve a dita Bernarda Maria a oradora sua filha, a qual foi exposta com todo o segredo e cautela em casa de Francisco Marques das Neves ${ }^{66}$.

Apesar dos alegados segredo e cautela, ao menos a própria Felisarda parecia conhecer a sua filiação. O Capitão Domingos Barreiros declarou que, quando ajustara o casamento, desconhecia o parentesco e que só depois de "haver entre eles maior familiaridade" é que ela lhe declarara "particularmente" que "tinha toda a certeza de ser sua sobrinha". Não tenho como saber se o que alegava o Capitão era verdade ou apenas uma estratégia para facilitar a dispensa que intentavam. De qualquer forma, parece claro que Felisarda mantinha proximidade com os parentes de sua mãe ou, pelo menos, com o seu tio, o Capitão Domingos Barreiros. No inventário, feito por ocasião da morte de seu primeiro marido, o Sargento-Mor João da Silva Ribeiro de Queirós, do qual Felisarda era a inventariante, foi ele o seu procurador.

Talvez, em função disto, ele sabia que ela havia herdado de seu marido uma fortuna considerável. Aliás, antes de sua morte, o Sargento-Mor havia vendido a meação dos bens do casal à esposa, pelo valor de 19:000\$000, segundo escritura lavrada em 22 de outubro de $1788^{67}$. Mas, apesar de alegar a necessidade de Felisarda se casar uma segunda vez, para que os seus negócios fossem bem administrados, o Capitão Domingos não conseguiu realizar aquele enlace, que lhe parecia ser tão benéfico. $\mathrm{Na}$ verdade, o processo matrimonial que haviam iniciado encontra-se incompleto, e, ao morrer, em 1800, o Capitão Domingos era solteiro e deixava 
como seus herdeiros quatro filhos naturais, todos havidos com Rita Maria da Conceição ${ }^{68}$. Felisarda, pelo conteúdo de seu testamento, escrito em 1812 , parece não ter-se casado uma segunda vez ${ }^{69}$. Talvez tenha percebido que poderia administrar os bens familiares, sem o "auxílio" de um novo esposo.

Além do conhecimento de sua filiação, a história de Felisarda ajuda também a pensar a inserção social dos expostos. Mesmo sendo exposta, casou-se com um grande negociante de fazenda seca e "sempre se trataram à lei da nobreza, com grande estimação de todos" 70 . Ao que tudo indica, os enjeitados - que conseguiam sobreviver aos altos índices de mortalidade infantil que os ameaçavam ${ }^{71}$ - eram inseridos na sociedade, sem maiores restrições à sua suposta origem pecaminosa.

Em São João del Rei, foram realizados, entre 1740 e 1850, 324 casamentos envolvendo expostos. Destes, $223(68,8 \%)$ uniram expostos a pessoas de filiação legítima; 66 (20,4\%), a filhos naturais; em 26 casos (8,0\%), não foi informada a legitimidade do cônjuge, e apenas nove $(2,8 \%)$ uniões foram celebradas entre dois expostos. Sheila de Castro Faria encontrou um quadro semelhante para Campos dos Goitacazes: em 76 casamentos envolvendo expostos, $65 \%$ os uniam a legítimos; $18 \%$, a naturais, $16 \%$, a pessoas de legitimidade ignorada, e havia um único caso de matrimônio entre dois enjeitados ${ }^{72}$. Ao que tudo indica, as famílias legitimamente constituídas não impunham obstáculos aos casamentos de seus filhos com expostos.

Dentre os 333 expostos que se casaram em São João del Rei, 134 (40,2\%) eram homens e 199 (59,8\%) mulheres. Também Carlos Bacellar, trabalhando com Sorocaba, entre 1679 e 1830, observou uma tendência semelhante, em termos do predomínio feminino entre os enjeitados que se casaram na região: $181(63,5 \%)$ eram mulheres e $104(36,5 \%)$ homens. Sobre isto, o autor afirma que

(...) esta proporção vai de encontro à igualdade entre os sexos identificada quando da exposição, mostrando que, por ocasião do casamento, as moças enjeitadas tinham maiores possibilidades de casar. $\mathrm{Ou}$, pelo menos, maiores chances de alcançar uma união conjugal diante do altar, já que não é possível contabilizar uniōes informais. Uma explicação para este fato é, no atual estágio dos conhecimentos, virtualmente impossível ${ }^{73}$. 
Embora não tenha como apresentar explicações cabais para esta tendência, creio que algumas hipóteses, pelo menos, podem ser aventadas. A primeira se relaciona ao fato de serem as mulheres, em geral menos migrantes que os homens, casando-se, no mais das vezes, no seu local de origem $^{74}$. Para elas, portanto, o conhecimento de seu enjeitamento seria mais imediato e, talvez, registrado com mais precisão nos assentos matrimoniais. Homens expostos, que se casassem em locais diferentes dos de seu batismo, poderiam mais facilmente encobrir sua legitimidade ou mesmo não precisar mencioná-la. Mais do que isto, porém, creio que deve ser considerado um dado importante, levantado por Sheila de Castro Faria, ao afirmar que

Há uma relação direta entre casamento e 'bom procedimento' para mulheres. Não encontrei nenhuma referência a 'bom procedimento' em relação a homens. Por outro lado, para incentivar este 'bom procedimento', os pais, quando estavam para morrer, costumavam aumentar o dote das filhas ainda solteiras, deixando-lhes, em testamento, o remanescente da terça. (...)

O mesmo pode ser dito em relação a meninas expostas, chamadas pelos recebedores de 'minha enjeitada', que recebiam esmolas consideráveis, como uma espécie de garantia de casamento. Todos os testadores, sem exceção, fixavam a cláusula "se se portasse bem" 75 .

Claro está que, assim como os pais se preocupavam mais com os casamentos das filhas que com os dos filhos, também os que criavam expostos pareciam mais preocupados com a "honra" de suas enjeitadas do que com a dos rapazes. Talvez, através delas também pudessem tecer novas teias e alianças sociais, afinal, pode-se supor, por exemplo, que, no bem sucedido casamento de Felisarda Matilde com o Sargento-Mor João Silva Ribeiro de Queirós, os seus criadores possam ter sido beneficiados. Quanto mais não seja, pelo acesso ao crédito daquele negociante.

Com os dados de que disponho, não posso chegar a conclusões mais sólidas quanto à inserção social dos expostos. Creio, porém, que, em grande parte, não eram discriminados pela sua condição. Podiam viver, em universos de riqueza ou pobreza, de acordo com o padrão social dos que os criaram e com a forma pela qual eram por eles tratados - como membros da família ou simplesmente agregados. Mas o enjeitamento não parecia conferir-lhes uma marca socialmente negativa. 


\section{Notas}

${ }^{1}$ Este artigo é versão ligeiramente modificada de parte de um dos capítulos de minha tese de doutorado, intitulada Minas Patriarcal - Família e Sociedade (São João del Rei, séculos XVIII e XIX), defendida na UFF, em 2002.

${ }^{2}$ Segundo Venâncio, a criação das "Casas da Roda" visava diminuir as trágicas situações de crianças abandonadas, no meio da noite, sujeitas a todo tipo de perigo - frio, animais, etc. - que, muitas vezes, não sobreviviam. Desta forma, procurava-se "civilizar" o abandono. A Santa Casa de Misericórdia do Rio de Janeiro começou a prestar assistência aos expostos em 1738 e a de Salvador em 1726. Cf. VENÂNCIO, Renato Pinto. Famílias Abandonadas: Assistência à Criança de Camadas Populares no Rio de Janeiro e em Salvador - Séculos XVIII e XIX. Campinas: Papirus, 1999, pp. 23-31.

${ }^{3}$ BACELLAR, Carlos de Almeida Prado. Viver e Sobreviver em uma Vila Colonial: Sorocaba, Séculos XVIII e XIX. S.P.: Annablume/FAPESP, 2001.

${ }^{4}$ Sobre os abandonos de crianças em rodas, Cf. VENÂNCIO, Renato Pinto, op. cit.; RUSSELL-WOOD, A.J.R. Fidalgos e Filantropos. A Santa Casa da Misericórdia da Bahia, 1550- 1775. Brasília: EDUNB, 1981.

${ }^{5}$ Cf. FARIA, Sheila de Castro. A Colônia em Movimento: Fortuna e Família no Cotidiano Colonial. RJ: Nova Fronteira, 1998; BACELLAR, Carlos de Almeida Prado, op. cit..

${ }^{6}$ Renato Pinto Venâncio adverte sobre os riscos a que o pesquisador menos atento pode estar sujeito na quantificação dos expostos. A questão por ele levantada diz respeito a que se deve considerar o percentual de expostos em relação ao número total de batismos realizados ou apenas aos de crianças livres. Considera mais correto o procedimento de excluir os batizados de escravos do universo analisado, uma vez que os expostos eram considerados livres. Cf. VENÂNCIO, Renato Pinto, op. cit., p. 45.

${ }^{7}$ BACELLAR, Carlos de Almeida Prado, op. cit., p. 197.

${ }^{8}$ FARIA, Sheila de Castro, op. cit., p. 70.

${ }^{9}$ Não pretendo com esse argumento retomar a idéia - já bastante criticada - de uma "involução" econômica de Minas, mas acredito que, na medida em que o setor que havia justificado a própria ocupação das Gerais entrou em declínio, as formas de organização familiar devem ter sido redefinidas, assim como o foi a própria economia, ainda que não partindo do zero, mas conferindo nova dimensão a atividades já anteriormente praticadas, como o comércio e a produção de alimentos. Diversos índices de comportamento familiar, como, por exemplo, os de legitimidade e as idades matrimoniais, sofreram alterações significativas, a partir desta década. Sobre estas mudanças, cf. BRÜGGER, Silvia Maria Jardim. Minas Patriarcal - Família e Sociedade (São João del Rei-séculos XVIII e $X I X)$. Tese de doutorado apresentada ao Programa de Pós-Graduação em História Social da UFF. Niterói, 2002.

${ }^{10} \mathrm{O}$ autor não dispõe de dados sobre a década de 1781 a 1790.

${ }^{11}$ BACELLAR, Carlos de Almeida Prado, op. cit., p. 194. 
12 BURMESTER, Ana Maria de O. Population de Curitiba au XVIIIe. Siècle. Tese de Ph.D. pela Universidade de Montreal. Montreal, 1981, apud BACELLAR, Carlos de Almeida Prado, op. cit.

${ }^{13}$ BACELLAR, Carlos de Almeida Prado, op. cit.., pp. 198-199.

${ }^{14}$ SOUZA, Laura de Mello e. Norma e Conflito: Aspectos da História de Minas no Século XVIII. BH: Editora UFMG, 1999, p. 50.

15 Também na região do Baixo-Minho, em Portugal, foi constatado um aumento dos enjeitamentos no último quartel do século XVIII. Cf. AMORIM, Maria Norberta. "História da Família em Portugal: Uma História em Marcha”. In: AMORIM, M.N. \& SILVA, M.B.N. da (Org.). A Família na História. Revista Ler História, no 29, 1995, p. 11.

${ }^{16}$ RESENDE, Diana Campos. Roda dos Expostos: Um caminho para a Infância Abandonada. Monografia apresentada ao Curso de Especialização em "História de Minas - Século XIX” da FUNREI. São João del Rei, 1996.

${ }^{17}$ Em 22 casos não foi possível identificar o sexo da criança exposta.

${ }^{18}$ BACELLAR, Carlos de Almeida Prado, op. cit., pp.199-200. Os trabalhos citados por este autor, para outras regiōes brasileiras, são: VENÂNCIO, Renato Pinto. "Crianças sem Amor: o abandono de recém-nascidos na cidade de São Paulo (1760-1860)”. Seminário permanente de estudo da família e da população no passado brasileiro. SP: IPE/USP, s/ d.; e SILVA, Maria Beatriz Nizza da. "O Problema dos Expostos na Capitania de São Paulo". Anais do Museu Paulista. S.P.: USP, 1980/81.

${ }^{19}$ RUSSEL-WOOD, A. J. R., op. cit., p. 246.

${ }^{20}$ VENÂNCIO, Renato Pinto, op. cit., 1999.

${ }^{21}$ FARIA, Sheila de Castro, op. cit., p. 76.

${ }^{22}$ Ibidem; MATTOS DE CASTRO, Hebe Maria. Das Cores do Silêncio: O Significado da Liberdade no Sudeste Escravista - Brasil-Séc. XIX. RJ: Arquivo Nacional, 1995.

${ }^{23}$ Renato Pinto Venâncio, citando Boswell, afirma que esta determinação tivera origem no Direito Romano, sendo incorporada pelas leis européias da Época Moderna. Segundo Venâncio, visava-se, assim, impedir que crianças livres fossem escravizadas. A legislação portuguesa reafirmou tal imperativo em 1775. Cf. VENÂNCIO, Renato Pinto, op. cit. $\mathrm{O}$ autor refere-se ao trabalho de BOSWELL, J. The Kindness of Strangers. The abandonment of children in Western Europe from Late Antiquity to the Renaissance. Londres: Penguin Press, 1988.

${ }^{24}$ MNSP-SJDR, Livro no 11 de Registros Paroquiais de Batismo, p. 134.

${ }^{25}$ Ibidem.

${ }^{26}$ Cf. nota 22.

${ }^{27}$ MNSP-SJDR, Livro no 11 de Registros Paroquiais de Batismo, p. 134.

${ }^{28}$ Para Salvador, entre 1758 e 1762, 60,1\% das crianças que tinham sua cor indicada eram brancos; entre 1780 e 1800, 50,9\%; entre 1801 e $1850,51,5 \%$; entre 1851 e 1870; 16,9\%. Já os mestiços seriam 32,6\%, entre 1758 e 1762; 44,8\%, entre 1780 e 
1800; 44,00\% entre 1801 e 1850; 69,7\%, entre 1851 e 1870 . Os negros, entre 1758 e 1762, constituíam 1,2\%; entre 1780 e 1800, 2,6\%; entre 1801 e 1850, 3,7\%; e, entre 1851 e 1870, 12,0\%. Para o Rio de Janeiro, o autor apresenta dados apenas relativos à segunda metade do século XIX: entre 1864 e 1870, os brancos seriam 57,7\% dos enjeitados cuja cor fora registrada, passando, entre 1871 e 1880, a 36\%. Os mestiços, no primeiro período, seriam $31,3 \%$, passando, no segundo, a 48,4\%. E os negros passaram a representar de 10,8\%, entre 1864 e 1870, a 15,4\%, de 1871 a 1880 . Cf. VENÂNCIO, Renato Pinto, op. cit, 1999.

${ }^{29}$ Ibidem.

${ }^{30}$ FARIA, Sheila de Castro. "Mulheres Forras: Riqueza e Estigma Social". Revista Tempo, vol. 5, no 9. RJ: 7 Letras, julho de 2000.

${ }^{31}$ VENÂNCIO, Renato Pinto, op. cit., 1999, p. 50.

${ }^{32}$ Ibidem, p. 85.

${ }^{33}$ VENÂNCIO, Renato Pinto, op. cit., 1999, p. 94.

${ }^{34}$ MNSP-SJDR, Livro no 13 de Registros Paroquiais de Batismo, p. 421.

${ }^{35}$ MRSJDR, cx. 411. Inventário post-mortem de Mariana Cândida dos Santos, 1840.

${ }^{36}$ MRSJDR, cx. 265. Inventário post-mortem de Anastacio José de Sousa, 1805.

${ }^{37}$ MRSJDR, cx. 489. Inventário post-mortem do Capitão José Gomes da Costa e Maria Hilária da Silva, 1830.

${ }^{38}$ MRSJDR, cx. 404. Inventário post-mortem de Germana Nunes Maurícia, 1845.

${ }^{39}$ Embora a maioridade legal fosse aos 25 anos, os órfãos poderiam pleitear ao monarca sua antecipação, tomando posse de seus bens, caso conseguissem esta graça (os homens, a partir dos 20 anos, e as mulheres, dos 18). Cf. Ordenaçôes Filipinas, livro Terceiro, Tít. XLII. Lisboa: Fundação Calouste Gulbenkian. Fac-simile da Edição da Typographia do Instituto Philomathico, 1870.

${ }^{40}$ MRSJDR, cx. 404. Inventário post-mortem de Germana Nunes Maurícia, 1845.

${ }^{41}$ A respeito da obrigação dos pais de susterem seus filhos, é interessante a declaração feita por Emerenciana Esméria dos Santos, em seu testamento redigido em 25 de maio de 1836: "Declaro que nada devo ao Capitão João Joaquim Pereira, e posto este fizesse algumas curas como cirurgião a mim e à minha família, e mesmo desse algum remédio, foi tratado comigo de nada me levar em retribuição de lhe criar uma filha até a idade de quatro anos, não tendo recebido dele coisa alguma [grifo meu]”. MRSJDR, cx. 119. Testamento de Emerenciana Esméria dos Santos, 1846.

42 BACELLAR, Carlos de Almeida Prado, op. cit., p. 214.

${ }^{43}$ FARIA, Sheila de Castro. "Sinhás Pretas: Acumulação de Pecúlio e Transmissão de Bens de Mulheres Forras no Sudeste Escravista (Séculos XVIII e XIX)”. In: SILVA, Francisco C. T. da; CASTRO, Hebe M. Mattos de \& FRAGOSO, João L.R. (Org.). Escritos sobre História e Educação: Homenagem à Maria Yedda Leite Linhares. RJ: Mauad/FAPERJ, 2001.

${ }^{44}$ Foram expostas, quase que na mesma proporção, crianças de ambos os sexos às mulheres forras: $48 \%$ dos enjeitados eram do sexo feminino e $52 \%$ do masculino. 
${ }^{45}$ FARIA, Sheila de Castro, op. cit., 2001.

${ }^{46}$ MRSJDR, cx. 113. Testamento de Antonio Ferreira Rocha, 1811.

${ }^{47}$ MRSJDR, cx. 102. Testamento de Antonio Gonçalves Penha, 1805.

${ }^{48}$ MRSJDR, cx. 507. Inventário post-mortem de Felícia Barbosa da Silveira, 1817.

${ }^{49}$ MRSJDR, cx. 350. Inventário post-mortem de Ana Francisca Rodrigues, 1808.

${ }^{50}$ MRSJDR, cx. 303. Inventário post-mortem de Dionísio Gonçalves Pedreira, 1797.

${ }^{51}$ MRSJDR, cx. 489. Inventário post-mortem do Capitão José Gomes da Costa e de Maria Hilária da Silva, 1830.

52 Ibidem.

${ }^{53}$ MRSJDR, cx. 149. Testamento de Maria de Almeida, 1765.

${ }^{54}$ MRSJDR, cx. 408. Inventário post-mortem de Inácia Teodora de Jesus, 1831.

${ }^{55}$ MRSJDR, cx. 169. Inventário post-mortem de Ana Maria de Moura, 1816.

${ }^{56}$ MRSJDR, cx. 318. Inventário post-mortem de Cipriana Marcelina da Conceição, 1814.

${ }^{57}$ BACELLAR, Carlos de Almeida Prado, op. cit., p. 228.

${ }^{58}$ Nestes casos, estou considerando apenas as listas dos distritos pertencentes ao Termo da Vila de São João del Rei, pois, para a Vila, não foram arrolados os cativos. Cf. APM. Mapeamento Populacional dos Distritos de São João del Rei, 1831/32.

${ }^{59}$ MRSJDR, cx. 167. Inventário post-mortem do Capitão Antonio José Moreira, 1833.

${ }^{60}$ MRSJDR, cx. 469. Inventário post-mortem do Capitão Tomás Carlos de Souza, 1817.

${ }^{61}$ MRSJDR, cx. C. Inventário post-mortem de Marcelino Rodrigues Aquino e Maria Francisca Teixeira, 1837.

${ }^{62}$ MRSJDR, cx. 295. Inventário post-mortem de Jeronimo Souza Ferras, 1815.

${ }^{63}$ Nas matrículas de expostos feitas pela Câmara Municipal de São João del Rei, entre 1768 e 1832, constam vários registros de crianças que retornaram ao poder de "pessoas de obrigação legítima”. BMBC - Livros de matrícula de Expostos, nos 108 a 111.

${ }^{64}$ FARIA, Sheila de Castro, op. cit., 1998.

${ }^{65}$ Ibidem, p. 71.

${ }^{66}$ AEM, Arm. 2, Pasta 139. Processo de Banho Matrimonial de Domingos Rodrigues Barreiros e Felisarda Matilde Morais Salgado, 1789.

${ }^{67}$ MRSJDR, cx. 421. Inventário post-mortem do Sargento-Mor João da Silva Ribeiro de Queirós, 1788.

${ }^{68}$ MRSJDR, cx. 336. Inventário post-mortem do Capitão Domingos Rodrigues Barreiros, 1800 .

${ }^{69}$ MRSJDR, cx. 118. Testamento de Felisarda Matilde de Morais Salgado, 1826.

70 AEM, Arm 1, Pasta 35. Processo de Banho Matrimonial de Domingos Rodrigues Barreiros e Felisarda Matilde Morais Salgado, 1789. 
${ }^{71}$ Diversos trabalhos apontam a alta mortalidade entre as crianças expostas. Cf., entre outros, FARIA, Sheila de Castro, op. cit., 1998, p. 84; VENÂNCIO, Renato Pinto, $o p$. cit., 1999, pp. 99-119; LEITE, Miriam L. Moreira. Livros de Viagem (1803-1900). RJ: Ed. UFRJ, 1997, pp. 143-159. Nas matrículas de expostos feitas pela Câmara Municipal de São João del Rei, em 89 (30\%) registros, num total de 297 enjeitados matriculados, entre 1768 e 1832, consta que os pagamentos feitos às amas foram suspensos, em função da morte das crianças. BMBC, Livros de matrícula de Expostos, $\mathrm{n}^{\underline{\mathrm{os}}} 108$ a 111.

${ }^{72}$ FARIA, Sheila de Castro, op. cit., 1998, p. 85.

${ }^{73}$ BACELLAR, Carlos de Almeida Prado, op. cit., p. 237.

${ }^{74}$ Sobre esta tendência, em São João del Rei, ver BRÜGGER, SMJ, op. cit., em especial o capítulo 2 .

${ }^{75}$ FARIA, Sheila de Castro, op. cit., 1998, p. 75.

\section{Referências bibliográficas}

AMORIM, Maria Norberta. "História da Família em Portugal: Uma História em Marcha”. In: AMORIM, M.N. \& SILVA, M.B.N. da (Org.). A Familia na História. Revista Ler História, no 29, 1995.

BACELLAR, Carlos de Almeida Prado. Viver e Sobreviver em uma Vila Colonial: Sorocaba, Séculos XVIII e XIX. S.P.: Annablume/FAPESP, 2001.

BOSWELL, J. The Kindness of Strangers. The abandonment of children in Western Europe from Late Antiquity to the Renaissance. Londres: Penguin Press, 1988.

BRÜGGER, Silvia Maria Jardim. Minas Patriarcal - Família e Sociedade (São João del Rei - séculos XVIII e XIX). Tese de doutorado apresentada ao Programa de Pós-Graduação em História Social da UFF. Niterói, 2002.

FARIA, Sheila de Castro. A Colônia em Movimento: Fortuna e Família no Cotidiano Colonial. RJ: Nova Fronteira, 1998.

FARIA, Sheila de Castro. "Mulheres Forras: Riqueza e Estigma Social”. Revista Tempo, vol. 5, n 9. RJ: 7Letras, julho de 2000.

FARIA, Sheila de Castro. "Sinhás Pretas: Acumulação de Pecúlio e Transmissão de Bens de Mulheres Forras no Sudeste Escravista (Séculos XVIII e XIX)". In: SILVA, Francisco C. T. da; CASTRO, Hebe M. Mattos de \& FRAGOSO, João L.R. (Org.). Escritos sobre História e Educação: Homenagem à Maria Yedda Leite Linhares. RJ: Mauad/FAPERJ, 2001.

LEITE, Miriam L. Moreira. Livros de Viagem (1803-1900). RJ: Ed. UFRJ, 1997.

MATTOS DE CASTRO, Hebe Maria. Das Cores da Silêncio: O Significado da Liberdade no Sudeste Escravista - Brasil-Séc. XIX. RJ: Arquivo Nacional, 1995. 
RESENDE, Diana Campos. "Roda dos Expostos: Um caminho para a Infância Abandonada". Monografia apresentada ao Curso de Especialização em "História de Minas - Século XIX” da FUNREI. São João del Rei, 1996.

RUSSELL-WOOD, A.J.R. Fidalgos e Filantropos. A Santa Casa da Misericórdia da Bahia, 1550- 1775. Brasília: EDUNB, 1981.

SILVA, Maria Beatriz Nizza da. "O Problema dos Expostos na Capitania de São Paulo”. Anais do Museu Paulista. S.P.: USP, 1980/81.

SOUZA, Laura de Mello e. Norma e Conflito: Aspectos da História de Minas no Século XVIII. BH: Editora UFMG, 1999.

VENÂNCIO, Renato Pinto. "Crianças sem Amor: o abandono de recém-nascidos na cidade de São Paulo (1760-1860). Seminário permanente de estudo da família e da população no passado brasileiro". SP: IPE/USP, s/d.

VENÂNCIO, Renato Pinto. Famílias Abandonadas: Assistência à Criança de Camadas Populares no Rio de Janeiro e em Salvador - Séculos XVIII e XIX. Campinas: Papirus, 1999.

\section{Resumo}

Neste artigo, analiso a exposição de crianças em São João del Rei, no século XVIII e na primeira metade do XIX, tanto em termos das variaçôes nos indices desta prática, quanto das motivaçôes que a estimulavam e das relaçōes que envolviam crianças, pais biológicos e os que recebiam os enjeitados em suas casas. Procuro analisar ainda alguns indícios sobre a inserção social dos expostos, ao longo de suas vidas. As principais fontes utilizadas são os registros paroquiais de batismo e casamento da Matriz de Nossa Senhora do Pilar de São João del Rei, inventários post-mortem, testamentos e listas nominativas.

Palavras-chave: Enjeitamento; Moralidade; Familia.

\section{Abstract}

In the present article, I analysed the forsake of children at São João del Rei during the XVIII century and the first half of the XIX. I looked for the variations in the index of that practice, the motivations that stimulated it and the relationships between the children, the biological parents and the ones who received the foundling in their houses. I searched some trace about the social introduction of the foundling during their whole lifes. The most used source of information were the baptism parish registers, from the Matriz de Nossa Senhora do Pilar de São João del Rei, testament and inventories post-mortem and São João del Rei nominative list.

Key Words: Foundlings; Morality; Family 